\title{
PENGEMBANGAN BAHAN AJAR TEMATIK BERMUATAN FOLKLOR BALI
}

\author{
Ni Ketut Desia Tristiantari \\ Jurusan Pendidikan Guru Sekolah Dasar, Universitas Pendidikan Ganesha \\ Email: ketut.desia@undiksha.ac.id
}

\begin{abstract}
Abstrak
Penelitian ini bertujuan untuk memeroleh bahan ajar tematik bermuatan folklor bali yang valid, praktis, dan efektif sebagai upaya untuk meningkatkan literasi membaca siswa kelas IV. Bahan ajar yang dikembangkan berupa buku penunjang buku siswa dan buku petunjuk guru pada tema "Tempat Tinggalku" dengan subtema 1 yaitu "Lingkungan Tempat Tinggalku". Penelitian ini menggunakan metode penelitian pengembangan atau Research and Development ( $R$ \& D) dengan mengadaptasi langkah-langkah model yang dikembangkan oleh Borg dan Gall yang disederhanakan, meliputi 1) tahap pengumpulan data, (2) tahap perencanaan, (3) tahap pengembangan produk, dan (4) tahap validasi dan uji coba. Adapun hasil penelitian ini adalah 1) Hasil penilaian ahli materi terhadap bahan ajar bermuatan folklore bali ada pada skor 4,25. Hal ini menunjukkan bahwa bahan ajar tematik bermuatan folklore ada pada kategori valid; (2) Hasil penilaian ahli desain pembelajaran ada pada skor 4,3. Hal ini menunjukkan bahwa bahan ajar tematik bermuatan folklore ada pada kategori valid, sehingga dapat dilanjutkan pada tahapan berikutnya, yaitu tahapan uji coba terbatas; (3) Hasil uji coba terbatas menunjukkan bahwa respon siswa terhadap bahan ajar tematik bermuatan folklore bali ini ada pada skor 4.4. Hal ini menunjukkan bahwa respon siswa terhadap bahan ajar bermuatan folklore ada pada kategori "positif.
\end{abstract}

Kata kunci: bahan ajar tematik, folklor bali, literasi membaca

\begin{abstract}
This study aims to develop valid, practical, and effective thematic material with Balinese folklore as an effort to improve literacy in reading fourth grade students. Teaching materials developed in the form of supporting books on student books and teacher manuals on the theme "My Place of Rest" with sub-theme 1, namely "My Neighborhood". This study uses the research and development $(R \& D)$ method by adapting the simplified model steps developed by Borg and Gall, covering 1$)$ the stage of data collection, (2) the planning stage, (3) the stage of product development, and (4) validation and trial stages. The results of this study are 1) The results of the expert assessment of material on Balinese folklore teaching materials are at a score of 4.25. This shows that folklore-themed thematic teaching material is in the valid category; (2) The results of the assessment of learning design experts are at a score of 4.3. This shows that folklore-themed thematic teaching material is in the valid category, so that it can be continued at the next stage, namely the stages of the trial are limited; (3) The results of a limited trial show that the students' response to thematic teaching material with Balinese folklore is at a score of 4.4 . This shows that students' responses to folklore-loaded teaching materials are in the "positive" category.
\end{abstract}

Keyword: teaching material, character education, Treffinger's model

\section{Pendahuluan}

Pembelajaran tematik merupakan pembelajaran yang sifatnya terpadu dengan penggunaan tema untuk menjaring secara keterkaitan dari berbagai bidang studi, tema-tema tersebut harus subur artinya tema tersebut mengundang banyak konsep dari berbagai bidang studi (Fogarty, 1991). Pembelajaran integratif didefinisikan sebagai pembelajaran yang menghubungkan berbagai gagasan, konsep, keterampilan, sikap, dan nilai, baik antar mata pelajaran maupun dalam satu mata pelajaran (Permendikbud No. 57, 2014).

Dalam pembelajaran, buku teks merupakan sarana penting yang digunakan untuk menunjang suatu program pengajaran. Hal ini tertuang dalam Peraturan Pemerintah Nomor 32 Tahun 2013 tentang Standar Nasional Pendidikan, "Buku teks adalah sumber pembelajaran utama untuk mencapai Kompetensi Dasar dan Kompetensi Inti". Dalam kurikulum 2013, buku yang digunakan sebagai salah satu sarana implementasi pembelajaran adalah buku siswa dan buku petunjuk guru. Buku Guru merupakan pedoman bagi guru dalam melaksanakan pembelajaran yang meliputi persiapan, pelaksanaan, dan penilaian serta pedoman penggunaan buku siswa. Buku guru terdiri atas dua bagian, yaitu petunjuk umum pembelajaran dan petunjuk khusus pelaksanaan pembelajaran pada setiap bab sesuai dengan buku siswa.

Buku petunjuk guru dan buku siswa merupakan buku yang disediakan Pemerintah melalui suatu penerbit secara Nasional. Berdasarkan wawancara yang dilaksanakan pada bulan Mei 2017 dengan guru kelas IV di SD Laboratorium Undiksha, buku guru memberikan banyak manfaat bagi pelaksanaan pembelajaran karena buku dikemas dalam bentuk yang menarik, dilengkapi dengan pemetaan KD dan indikator pembelajaran, serta mudah dipahami. Namun, di sisi lain, buku ini dapat membingungkan siswa karena isi buku tidak sesuai dengan lingkungan dan budaya tempat siswa belajar. 
Karakteristik peserta didik di setiap wilayah Indonesia berbeda satu dengan yang lainnya, sehingga perlu dilakukan identifikasi unsur budaya lokal (kearifan lokal) dalam sumber belajar siswa untuk menjadikan kelas aktif guna mencapai pengalaman belajar bermakna (meaningfull) (Anderson \& Krathwohl, 2001). Pembelajaran bermakna akan dapat diperoleh jika anak belajar sesuai dengan lingkungan sosialnya, sehingga unsur budaya tidak bisa dilepaskan dalam merancang sebuah pembelajaran di sekolah. Selain itu, dalam kerangka kurikulum 2013 juga disebutkan bahwa dalam menyusun dan mengembangkan kegiatan pembelajaran harus memperhatikan prinsip-prinsip penyusunan dan pengembangan sesuai dengan kondisi di satuan pendidikan baik kemampuan awal peserta didik, minat, motivasi belajar, bakat, potensi, kemampuan sosial, emosi, gaya belajar, kebutuhan khusus, kecepatan belajar, latar belakang budaya, norma, nilai, dan/atau lingkungan peserta didik (Kemendikbud, 2013).

Kondisi ini menyebabkan kemampuan literasi membaca siswa tidak mampu dikembangkan. Literasi membaca digambarkan sebagai kemampuan untuk memahami dan menggunakan bahasa tulis yang diperlukan oleh siswa. Siswa dapat membangun makna dari berbagai teks dan mengambil bagian dalam masyarakat pembaca di sekolah serta dalam kehidupan sehari-hari. Di samping itu, kondisi ini tentunya dapat mempersulit siswa dalam memahami materi yang seharusnya mereka kuasai.

Secara empiris, kemampuan membaca siswa Indonesia di dunia internasional masih lemah. Studi internasional PISA tahun 2006 menyatakan bahwa kemampuan literasi membaca siswa Indonesia berada pada peringkat ke-48 dari 56 negara. Skor rata-rata membaca yang diperoleh siswa Indonesia adalah 393. Skor ratarata tertinggi dicapai oleh Korea (556) dan terendah dicapai Kyrgyzstan (285). Kemampuan literasi membaca ratarata siswa Indonesia tidak berbeda secara signifikan dengan kemampuan literasi membaca siswa dari Bulgaria, Serbia, Jordania, Romania, Brazil, Montenegro, Colombia, dan Tunisia. Kemampuan literasi membaca rata-rata siswa Indonesia lebih tinggi secara signifikan daripada kemampuan literasi membaca siswa dari Argentina, Azerbaijan, Qatar, dan Kyrgyzstan.

Hal senada hasil studi PIRLS memperlihatkan bahwa Skor prestasi membaca rata-rata siswa Indonesia adalah 407, menduduki posisi ke lima dari urutan bawah, di atas Qatar (353), Kuwait (330), Maroko (323), dan Afrika Selatan (302). Rata-rata prestasi membaca internasional adalah 500. Hasil studi PISA dan PIRLS ini menjadi cambuk bagi dunia pendidikan di Indonesia. Pendidikan di Indonesia sudah seharusnya berbenah dalam hal meningkatkan motivasi membaca siswa di sekolah.Bahan ajar cetak kurang mengedepankan unsur lingkungan dan budaya lokal masyarakat setempat, sehingga guru sebagai pendidik yang profesional harus menyiapkan bahan ajar yang memperhatikan kondisi lingkungan dan budaya masyarakat setempat (Laksana, 2015). Bertolak dari permasalah tersebut, peneliti tertarik untuk mengembangkan bahan ajar tematik yang dapat menciptakan pembelajaran bermakna bagi siswa, yaitu melalui pengembangan bahan ajar tematik bermuatan folklore bali.

Dengan mengembangkan bahan ajar tematik bermuatan folklor Bali, pembelajaran tematik di Sekolah Dasar, khususnya di Buleleng, dapat terlaksana sesuai budaya setempat sehingga tidak membingungkan siswa. Di samping itu, folklore bali yang selama ini hanya diwariskan secara turun temurun dari mulut ke mulut mulai berkurang eksistensinya. Hal ini disebabkan cerita-cerita fiksi dari budaya luar semakin mudah diakses. Agar folklore bali ini tidak segera punah, pengenalan folklore bali bisa dikenalkan di lingkup pendidikan formal, salah satunya di sekolah. Berkaitan dengan hal tersebut maka penulis tertarik untuk melakukan penelitian pengembangan dengan judul Pengembangan Bahan Ajar Tematik Bermuatan Folklor Bali untuk Meningkatkan Kemampuan Literasi Siswa Kelas IV di Kabupaten Buleleng.

Berdasarkan latar belakang dan masalah yang telah dirumuskan sebelumnya, maka tujuan penelitian ini adalah untuk memeroleh draft bahan ajar tematik bermuatan folklor bali sebagai upaya meningkatkan literasi membaca siswa kelas IV, mengetahui hasil penilaian draft bahan ajar tematik bermuatan folklor bali, dan mengetahui respon siswa terhadap bahan ajar tematik bermuatan forklor bali.

\section{Metode Penelitian}

Penelitian ini menggunakan metode penelitian pengembangan atau Research and Development (R \& D). Penelitian yang dilakukan peneliti dalam pengembangan ini diadaptasi dari langkah-langkah pengembangan yang dikembangkan oleh Borg \& Gall tersebut dengan beberapa pembatasan. Borg \& Gall (dalam Emzir, 2013: 271) menyatakan bahwa dimungkinkan untuk membatasi penelitian dalam skala kecil, termasuk membatasi langkah penelitian. Karena keterbatasan waktu dan tenaga yang dimiliki peneliti, penerapan langkah-langkah pengembangannya disesuaikan dengan kebutuhan peneliti, sehingga langkah-langkah tersebut disederhanakan menjadi empat langkah pengembangan, yaitu (1) tahap pengumpulan data, (2) tahap perencanaan, (3) tahap pengembangan produk, dan (4) tahap validasi dan uji coba.

Penelitian ini dilaksanakan pada Sekolah Dasar di Kabupaten Buleleng. Pelaksanaan uji coba terbatas dilaksanakan di SD Negeri 1 Sulanyah dan SD Negeri 3 Ringdikit pada semester ganjil tahun ajaran 2018/2019. Rasionalitas pemilihan SD Negeri 1 Sulanyah dan SD Negeri 3 Ringdikit sebagai tempat pelaksanaan uji coba terbatas penelitian ini didasarkan atas pertimbangan keterjangkauan dan kelayakan. Keterjangkauan dimaksudkan kemudahan akses karena lokasi kerja dan tempat tinggal peneliti memiliki jarak yang cukup dekat dengan tempat pelaksanaan penelitian, sehingga kelancaran dalam penelitian dapat dijamin. Kelayakan yang dimaksud adalah SD 
Negeri 1 Sulanyah dan SD Negeri 3 Ringdikit memiliki sarana dan prasarana yang menunjang implementasi bahan ajar dalam penelitian itu. Di samping itu, pertimbangan kelayakan sekolah ini sebagai tempat uji coba terbatas adalah kesediaan guru yang mengajar kelas IV untuk bekerja sama. Instrumen yang digunakan dalam penelitian ini yaitu: (1) lembar validasi bahan ajar tematik bermuatan folklor, (2) angket respons siswa terhadap bahan ajar tematik bermuatan folklor, dan (3) angket respons guru terhadap bahan ajar tematik bermuatan folklore.

\section{Hasil dan Pembahasan}

Penelitian ini dilaksanakan dalam beberapa tahapan yaitu. (1) Tahap pengumpulan data. Tahap pengumpulan data dilakukan untuk mengetahui kebutuhan pembelajaran di lapangan. Tahap pengumpulan data dilakukan dengan cara studi lapangan dan studi pustaka. Studi lapangan dilakukan untuk mengetahui kebutuhan sumber belajar di sekolah. Studi lapangan dilakukan dengan cara analisis kurikulum yang berlaku di sekolah, analisis tahap perkembangan siswa, dan analisis ketersediaan sumber belajar di lapangan. Studi pustaka mengenai teori yang berhubungan dengan bahan ajar serta studi pustaka mengenai literasi membaca. (2) Tahap perencanaan. Tahap perencanaan dimulai dengan melakukan pemetaan materi pembelajaran yang akan disampaikan. Pemetaan materi dimulai dengan analisis Kompetensi Inti dan Kompetensi Dasar kemudian dilanjutkan dengan penentuan tema. Pada tahap perencanaan ini sekaligus direncanakan evaluasi sumber belajar yaitu dengan membuat kisi-kisi penilaian. (3) Tahap pengembangan produk. Pengembangan produk dilakukan dengan menentukan isi, cakupan bahan ajar, dan urutan isi bahan ajar yang akan dibuat. Peneliti juga menentukan strategi pengajaran yang akan digunakan untuk menyampaikan bahan ajar yang dikembangkan dengan cara merinci kegiatan belajar yang dilakukan siswa. Selanjutnya, pengumpulan bahan dari berbagai sumber, hingga pada tahap terakhir adalah menentukan evaluasi instrument pembelajaran untuk mengetahui ketercapaian tujuan. (4) Tahap validasi dan uji coba. Validasi desain digunakan peneliti sebagai evaluasi formatif I terhadap desain produk pengembangan bahan ajar. Produk yang telah dikembangkan akan divalidasi oleh tiga orang pakar yang terdiri atas pakar perencanaan pembelajarn, pakar pembelajaran terpadu, dan guru kelas IV pelaksana kurikulum 3013. Validasi produk ini bertujuan untuk memeroleh kritik dan saran serta penilaian terhadap produk yang dikembangkan sebagai pertimbangan sebelum dilakukan uji coba terbatas. Tahap selanjutnya adalah uji coba terbatas. Uji coba dilaksanakan pada dua sekolah dengan 36 subjek. Uji coba dilakukan dengan pengamatan, wawancara dan pengedaran angket.

Terdapat beberapa hal yang perlu disiapkan sebelum mengembangkan bahan ajar tematik bermuatan folklore bali yaitu silabus, RPP, buku guru, buku siswa, dan beberapa forklor bali. Beberapa dokumen lain yang disiapkan adalah pedoman pelaksanaan kurikulum 2013 yaitu Permendikbud Nomor 21 Tahun 2016 tentang Standar Isi Pendidikan Dasar dan Menengah, Permendikbud Nomor 22 Tahun 2016 tentang Standar Proses Pendidikan Dasar dan Menengah, dan Permendikbud Nomor 24 Tahun 2016 tentang KI dan KD Pelajaran pada Kurikulum 2013 pada Pendidikan Dasar dan Menengah

Tahap selanjutnya adalah mengidentifikasi tema pembelajaran yang akan dikembangkan bahan ajarnya. Tema yang terdapat pada pembelajaran tematik kelas IV adalah 1) Indahnya kebersamaan, 2) Selalu berhemat energy, 3) Peduli terhadap Makhluk hidup, 4) Berbagai Pekerjaanku, 5) Menghargai Jasa pahlawan, 6) Indahnya Negeriku, 7) Cita-citaku, 8) Daerah Tempat Tinggalku, dan 9) Makanan Sehat Bergizi.

Dari sembilan tema yang ada, ditentukanlah tema pembelajaran yang relevan untuk dikembangkan bahan ajar bermuatan folklore bali adalah tema ke delapan yaitu "Daerah Tempat Tinggalku". Tema 8 dipilih karena dianggap relevan untuk diintegrasiikan dengan folklore bali. Dianggap relevan, karena pada tema ini konten dalam mata pelajaran Bahasa Indonesia adalah "Cerita Fiksi". Salah satu contoh jenis cerita fiksi adalah folklore bali. Beberapa judul folklore bali yang telah disiapkan, disesuaikan dengan kompetensi dasar yang dibahas pada masing-masing pembelajarannya. Adapun judul folklore yang dikembangkan pada tema 8 subtema 1 "Lingkungan Tempat Tinggalku" adalah (1) Men Tiwas dan Kijang Putih, (2) Rare Angon dan Lubang Kuri, (3) Pan Balang Tamak, (4) Cupak dan Gerantang, dan (5) Bawang dan Kesuna.

Penilaian prototype bahan ajar tematik bermuatan folklore bali oleh ahli materi meliputi tiga aspek, yaitu 1) kelayakan isi, 2) Kelayakan Penyajian, dan 3) Kelayakan Bahasa. Ketiga aspek tersebut dikembangkan menjadi 20 item pernyataan. Adapun rentang skor yang diberikan pada masing-masing pernyataan adalah 1 sampai 5 dengan skor terendah 1 (sangat tidak setuju) dan skor tertinggi adalah 5 (sangat setuju). Hasil penilaian ahli materi menunjukkan bahwa rata-rata penilaian ahli materi ada pada skor 4,25. Hal ini menunjukkan bahwa bahan ajar tematik bermuatan folklore ada pada kategori valid.

Penilaian prototype bahan ajar tematik bermuatan folklore bali oleh ahli desain pembelajaran meliputi empat aspek, yaitu 1) desai pembelajaran, 2) strategi penyampaian pesan, 3) aspek fisik atau tampilan, 4) aspek bahasa. Keempat aspek tersebut dikembangkan menjadi 22 item pernyataan. Adapun rentang skor yang diberikan pada masing-masing pernyataan adalah 1 sampai 5 dengan skor terendah 1 (sangat tidak setuju) dan skor tertinggi adalah 5 (sangat setuju). Hasil penilaian ahli desai pembelajaran menunjukkan bahwa rata-rata penilaian ahli desain pembelajaran ada pada skor 4,3. Hal ini menunjukkan bahwa bahan ajar tematik bermuatan folklore ada pada kategori valid, sehingga dapat dilanjutkan pada tahapan berikutnya, yaitu tahapan uji coba terbatas. 
Berdasarkan penilaian beberapa ahli yang telah diuraikan sebelumnya, terdapat pula komentar dan saran perbaikan dari masing-masing ahli adalah sebagai berikut

Tabel 1. Komentar Perbaikan

\begin{tabular}{cl}
\hline Ahli & \multicolumn{1}{c}{ Komentar dan Saran Perbaikan } \\
1 & $\begin{array}{l}\text { Folklor bali yang digunakan seharusnya } \\
\text { dibuat lebih ringkas tanpa mengurangi isi dan } \\
\text { pesan yang terkandung di dalamnya } \\
\text { Tata tulis perlu dicermati sehingga tidak ada } \\
\text { kesalahan-kesalahan dalam penulisannya } \\
2\end{array}$ \\
Penggunaan bahasa perlu disederhakan lagi
\end{tabular}

Bahan ajar tematik bermuatan folklore ini selanjutnya diujicobakan secara terbatas dengan melibatkan 36 siswa kelas IV yang berasal dari dua sekolah yaitu, SD Negeri 1 Sulanyah dan SD Negeri 3 Ringdikit. Adapun hasil ujicoba respon siswa terhadap bahan ajar ini terbatas menunjukkan bahwa respon siswa terhadap bahan ajar tematik bermuatan folklore bali ini ada pada kategori "positif". Berdasarkan hasil uji coba tersebut, dapat dilihat terdapat beberapa aspek dengan skor tertinggi yaitu ilustrasi, kontekstual, dan penggunaan warna.

\section{Simpulan Dan Saran}

Hasil penilaian ahli materi terhadap bahan ajar bermuatan folklore bali ada pada skor 4,25.Hal ini menunjukkan bahwa bahan ajar tematik bermuatan folklore ada pada kategori valid. Hasil penilaian ahli desain pembelajaran ada pada skor 4,3. Hal ini menunjukkan bahwa bahan ajar tematik bermuatan folklore ada pada kategori valid, sehingga dapat dilanjutkan pada tahapan berikutnya, yaitu tahapan uji coba terbatas. Hasil uji coba terbatas menunjukkan bahwa respon siswa terhadap bahan ajar tematik bermuatan folklore bali ini ada pada skor 4.. Hal ini menunjukkan bahwa respon siswa terhadap bahan ajar bermuatan folklore ada pada kategori "positif".

Terdapat beberapa saran untuk penelitian ini, yaitu perlu diadakan pengembangan lebih lanjut terhadap bahan ajar tematik bermuatan folklore bali dengan memanfaatkan teks kearifan lokal untuk melengkapi kekurangan pada bahan ajar tersebut. Di samping itu, perlu diadakan penelitian lebih lanjut untuk menguji efektivitas penggunaan bahan ajar tematik bermuatan folklore bali dengan media atau pendekatan lainnya.

\section{Daftar Pustaka}

Anderson, L.W. \& Krathwohl, D.R. (2001). A Taxonomy for Learning, Teaching, and Assessing. Abridged Edition. New York: Addison Wesley Longman, Inc.

Emzir, 2013. Metodologi Penelitian Pendidikan. Depok: PT. Raja Grafindo Persada.

Ermadwicitawati, N.M. 2013. Pengembangan Materi Ajar Cerita Anak yang Mengandung Pendidikan Karakter pada Pembelajaran Membaca Cerita Anak SMP Kelas VII di Singaraja. e-Journal Program Pascasarjana Universitas Pendidikan Ganesha, Program Studi Pendidikan Bahasa dan Sastra Indonesia, Volume 2.

Fogarty, R. (1991). The Mindfull School: How to Integrate the Curricula. Paltine: Skyligh Publishing, Inc

Kemendikbud. 2013. Penyusunan Rencana Pelaksanaan Pembelajaran. Jakarta: Kepala Badan Pengembangan Sumber Daya Manusia Pendidikan dan Kebudayaan dan Penjaminan Mutu Pendidikan.

Kemendikbud. 2014. Peraturan Menteri Pendidikan dan Kebudayaan Nomor 57 Tahun 2014. Jakarta: Kemendikbud.

Laksana, D.N L. \& Wawe, F. (2015). Penggunaan Media Berbasis Budaya Lokal Dalam Pembelajaran IPA untuk Meningkatkan Aktivitas dan Pemahaman Konsep IPA Siswa Sekolah Dasar. Jurnal Ilmiah Pendidikan Citra Bakti, 2 (1), 27-37.

Laksana, D.N.L. dkk. (2016) Pengembangan Bahan Ajar Tematik SD Kelas IV Berbasis Kearifan Lokal Masyarakat Ngada. Jurnal Ilmiah Pendidikan Citra Bakti, Volume 2 Nomor 1. ISSN: 2355-5106.

Mullis, I.V.S., Martin, M.O.,Gonzales, E.J., Gregory, KD., Garden, R.A.,O’Connors,KM.,Krostowski, S.J., danSmith, T.A. 2007. TIMSS: Trends in Mathematics and Science Study: Assessment Specification 2006. Boston : The International StudyCenter.

Nugroho, Agung. 2013. Pengembangan Bahan Ajar Sastra Berbasis Cerita Rakyat Musi Rawas Kelas V SD Negeri Karyadadi Kabupaten Musi Rawas. Tesis (tidak diterbitkan). Universitas Bengkulu.

Oxford Advance Learners Dictionary Internationak Student;s 8th edition.2010. New York: Oxford University Press.

Pemerintah Republik Indonesia. 2013. Peraturan Pemerintah Republik Indonesia Nomor 32 Tahun 2013 tentang Perubahan atas Peraturan Pemerintah Nomor 19 Tahun 2005 Standar Nasional Pendidikan. Jakarta.

Rosenblatt, Louise M. 1978. The Reader, the Text, the Poem: The Transactional Theory of the Literary Work. Ilinois: Southem Ilinois University Press.

Ruhimat, Toto dkk. 2011. Kurikulum dan Pembelajaran. Jakarta. PT Raja Grafindo Persada. 
Sadra, I W. 2007. Pengembangan Model Pembelajaran Matematika Berwawasan Lingkungan dalam Pelatihan Guru Kelas I Sekolah Dasar. Desertasi Tidak Dipublikasikan. Program Doktor Universitas Negeri Surabaya.

Sukmadinata. 2006. Metode Penelitian Pendidikan. Bandung: Rosdakarya.

Sumarwan, Eri. 2016. Literasi Anak. Yogyakarta: Gambang Buku Budaya. 